Kocaeli Üniversitesi Sağlık Bilimleri Dergisi

\title{
SELECTION OF SITE FOR ADMINISTRATION OF INTRAMUSCULAR INJECTION TO ADULT PATIENTS BY NURSES: A CROSS-SECTIONAL STUDY
}

\author{
HEMŞIRELERIN INTRAMUSKÜLER ENJEKSIYON BÖLGESİ SEÇIMINİ ETKILLEYEN FAKTÖRLER: \\ KESITSEL BIR ÇALIŞMA
}

\author{
(D) Nuray Turan ${ }^{1}$ @(Dülsün Özdemir Aydın²*, (iDurten Kaya ${ }^{3}$
}

${ }^{1}$ Istanbul University-Cerrahpasa, Florence Nightingale Nursing Faculty, Istanbul, Turkey

${ }^{2}$ Tekirdag Namık Kemal University, School of Health, Department of Nursing, Tekirdag, Turkey

${ }^{3}$ Istanbul University-Cerrahpasa, Faculty of Health Sciences, Istanbul, Turkey

ORCID iD: Nuray Turan: 0000-0002-8362-3427; Gülsün Özdemir Aydın: 0000-0003-0550-3195; Nurten Kaya: 0000-0003-0414-3589

*Corresponding Author / Sorumlu Yazar: Gülsün Özdemir Aydın, e-mail / e-posta: gulsunozdemir@nku.edu.tr

\begin{tabular}{lll} 
Geliş Tarihi / Received: 28.02.2019 Accepted / Kabul Tarihi: 16.07.2019 Published / Yayım Tarihi: 06.09.2019 \\
\hline
\end{tabular}

\begin{abstract}
Objective: This study was carried out to determine the sites which are selected by nurses to use in the intramuscular medicine applications and the factors affecting the selection of the injection sites.

Methods: The population of this descriptive and cross-sectional type of study was composed of 250 nurses working in two hospitals in Istanbul, the sample was composed of 171 nurses selected by stratified random sampling method. Data were collected with 'Structured Questionnaire Form'

Results: The average age of the nurses was found to be $26.27 \pm 7.46$ years, it was determined that $40.4 \%$ of them applied injection very often and they preferred dorsogluteal site to apply injection with a ratio of $83.6 \%$. When the knowledge level of nurses about the complications that may occur depending injection site, it was seen that some nurses did not consider complications such as pain, nerve, bone and vascular injury, infection, necrosis, tissue irritation, nodules or stiffness, abscess and hematoma in the deltoid site. On the other hand, it was learnt that they had a risk of developing sciatic nerve damage in the ventrogluteal site. The unit, which the nurses work and the experience period in that unit affects the site selection in injection application. As a result, nurses often prefer the dorsogluteal site in injection.

Conclusion: The nurses' knowledge about the complications that may ocur in the sites chosen for injection by them is insufficient and there are factors affecting the selection of the site.
\end{abstract}

Keywords: Intramuscular injections, ventrogluteal site, dorsogluteal site, deltoid site, laterofemoral site

\section{$\ddot{O} z$}

Amaç: Bu çalışma hemşirelerin intramusküler ilaç uygulamalarında seçtiği enjeksiyon bölgeleri ile bölge seçimini etkileyen faktörleri belirlemek amaciyla yapildi.

Yöntem: Tanımlayıcı ve kesitsel türdeki bu araştırmanın evreni İstanbul'daki iki hastanede çalışan 250 hemşire; örneklemini ise tabakalı rastgele örnekleme yöntemi ile seçilen 171 hemşire oluşturdu. Veriler, 'Yapılandırılmış Soru Formu' ile toplandı.

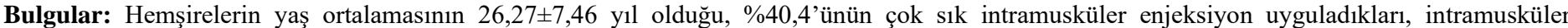
enjeksiyon için \%83,6 oranla öncelikli olarak dorsogluteal bölgeyi tercih ettikleri belirlendi. Hemşirelerin intramusküler enjeksiyon bölgesine göre gelişebilecek komplikasyonlar hakkında bilgi düzeyleri incelendiğinde; bazı hemşirelerin ağrı, deltoid bölgede sinir, kemik ve damar yaralanması, enfeksiyon, nekroz, doku tahrişi, nodül veya sertlik, apse ve hematom gibi komplikasyonları bir risk olarak görmedikleri öte yandan ventrogluteal bölgede siyatik sinir hasarı gelişme riskinin bulunduğunu ifade ettikleri görüldü. Hemşirelerin çalıştıkları ünite ve ünitedeki deneyim süresi intramusküler enjeksiyon uygulamasında bölge seçimini etkilemektedir. Sonuç olarak, hemşireler intramusküler enjeksiyon uygulamasında sıklıkla dorsogluteal bölgeyi tercih etmektedir.

Sonuç: İntramusküler enjeksiyon için seçtikleri bölgelerde gelişebilecek komplikasyonlar konusundaki bilgileri yetersizdir ve bölge seçimini etkileyen faktörler bulunmaktadır.

Anahtar Kelimeler: Intramusküler enjeksiyon, ventrogluteal bölge, dorsogluteal bölge, deltoid bölge, laterofemoral bölge 


\section{Introduction}

The responsibilities of the nurses in medical institutions include preparation of medications, their safe administration, educating patients and their relatives on the use of medications, and following patients' reactions to medication. The bulk of their responsibility consists of administering medications and they are responsible for delivering the right drug at a right dose at the correct time and administering it via an appropriate route and keeping the record of it. ${ }^{1-4}$

Drugs can be administered in different ways namely oral, topical, and parenteral. ${ }^{4}$ Intramuscular injections (IM), one of the ways of parenteral administration of drugs, are used to administer medication into large muscles. Due to the existence of more vessels in muscles, IM injection is absorbed better compared with subcutaneous injection. Besides, needle depth, syringe length, and administration pace need to be welldetermined for IM injection. ${ }^{5}$ However, the World Health Organization has estimated that of the approximately 12 billion injections globally administered every year, $50 \%$ are administered in an unsafe manner. ${ }^{6}$ In other words, IM injections involve a lot of risks. Complications that might occur include abscess, necrosis, infection, tissue damage, hematoma, chronic pain, injuries to nerve, bone, and vein, periostitis, and contracture., , $^{3,7-10}$ The most important complication, however, is sciatic nerve damage and it takes place particularly due to injections delivered to dorsogluteal (DG) site. ${ }^{1,2,11}$ The sciatic nerve is the most frequently affected nerve, particularly in children, the elderly, and underweight patients ${ }^{6}$. In the literature, it is stated that, in cases where health professionals have the necessary knowledge and skills about intramuscular injections, these complications can be prevented or reduced. ${ }^{1,2,9,11}$

Until recently, sites selected for IM injection were stated to be DG, ventrogluteal (VG), lateral femoral, and deltoid site. ${ }^{12,13}$ However, recent literature ${ }^{2,4,12,13}$ shows that DG is the riskiest site because it is rich in nerves, close to sciatic nerve, and its subcutaneous tissue is thicker compared to others and thereby, it should not be preferred. The VG site is the safest injection site for adults and children over the age of 7 months. Because it has no nerves or large blood vessels, it is far away from bone protrusions, the possibility of delivering the medication to subcutaneous tissue is low, the location is easy to determine anatomically, and it has a large area of muscle..$^{2,4,12-16}$

In the literature, it is pointed out that it is crucial to choose a safe site away from the large blood vessels, nerve and bone structures for intramuscular injections. ${ }^{3,13,14}$ Thus, nurses are required to have a good command over the anatomic structure of the administration site and make wise choices. ${ }^{4,7,9}$ Studies conducted by Sar1 et al. $^{8}$ as well as Floyd and Meyer ${ }^{10}$ confirmed that nurses quite frequently prefer DG site to deliver medication. In addition, studies show that although administration of IM injections is one the most common responsibility of nurses, their knowledge of IM injection, administration sites, and methods is insufficient and it is not evidence-based. ${ }^{4,9,10,17}$

Study questions:

1. To what extent are the nurses familiar with the complications that might occur at the sites of IM injections?

2. How do the individual and professional characteristics of nurses affect their selection of site for IM injection?

\section{Methods}

\section{Study Design}

This descriptive and cross-sectional study was conducted to determine the sites chosen by nurses while administering intramuscular injections and explore the factors that affect these choices.

\section{Setting and Sample}

The study population comprised 250 nurses working at two private hospitals in 2016. The sample, on the other hand, was composed of 171 nurses (68.4\% of population), who were selected through stratified random sampling method (stratum criteria is hospitals). In addition, it was found that the sample had the power to represent the population with an error of $\pm 4 \%$ at $95 \%$ confidence level.

\section{Measurements}

The data of the study were collected using Structured Question Form developed by the researchers in line with the literature. .,7,13,18-21 $^{-1}$

Structured Question Form: The first part of the form included individual and professional facts, such as age, professional education, type of unit they work for, experience in a certain unit, and professional experience. The second part comprised questions inquiring IM injection site and frequency of injections, factors affecting selection of IM injection site, possible complications likely to occur at the site of administration, and whether they receive any training/information about identifying IM injection site.

\section{Data Collection}

Data were collected between February 29, 2016 and April 8, 2016. Verbal permission was obtained from each nurse after explaining the study aims, process, procedural details, participants' rights, and potential benefits and risks. We also informed them that they could contact the research team with any questions. The research team interviewed face to face for 10-15 minutes.

\section{Data Analysis}

IBM SPSS Statistics 22 (IBM SPSS, Turkey) was utilized for statistical analysis of the data. Descriptive statistics were expressed as mean, standard deviation, minimum, and maximum for continuous variables, and as frequency and percentage for categorical variables. The comparison of two categorical groups was made using chi square test. Level of significance was accepted as $p=0.05$.

\section{Results}

In this section, there are four parts that explore individual and professional characteristics of nurses, their features about administering IM injection, how familiar they are with potential complications at a certain IM injection site, and how their individual and professional characteristics influence their decision-making for IM injection practices.

\section{Individual and Professional Characteristics of Nurses}

Table 1 shows that mean age of the nurses was $26.27 \pm 7.46$ $(\min =18, \max =55)$ years and $59.6 \%$ of them were in the age group 18-25. The mean professional experience was found to be $68.96 \pm 84.53$ ( $\min =1, \max =456$ ) months; $80 \%$ of them had an experience of 1-10 years. The mean duration of experience in the unit they worked for was $32.78 \pm 38.41$ ( $\min =1$, $\max =180$ ) months 
and $79.5 \%$ of them had an experience of 1-10 years in that unit. As for education, the majority of the nurses $(62.6 \%)$ were vocational high school graduates, followed by bachelor's (19.9\%) and associate's degree (17.5\%). When the type of unit they worked for is considered, it is seen that $31.6 \%$ of them were in the intensive care unit (ICU), $17.5 \%$ were in operating units, $15.8 \%$ were in emergency, $14.0 \%$ were in gynecology /delivery room, $8.2 \%$ were in pediatrics, $6.4 \%$ were in operating room, and finally $6.4 \%$ of them worked in administration or other units.

Table 1. Nurses individual and professional characteristics $(n=171)$

\begin{tabular}{|c|c|c|}
\hline $\begin{array}{l}\text { Individual and Professional } \\
\text { Characteristics }\end{array}$ & $\mathbf{n}$ & $\%$ \\
\hline \multicolumn{3}{|l|}{ Age Groups (Year) } \\
\hline $18-25$ & 102 & 59.6 \\
\hline $26-33$ & 44 & 25.7 \\
\hline $34-41$ & 18 & 10.5 \\
\hline 42 and above & 7 & 4.1 \\
\hline \multicolumn{3}{|l|}{ Professional Education } \\
\hline Vocational High School & 107 & 62.6 \\
\hline Associate's Degree & 30 & 17.5 \\
\hline Bachelor & 34 & 19.9 \\
\hline \multicolumn{3}{|l|}{ Experience in Job } \\
\hline 1 year below & 7 & 4.1 \\
\hline $1-10$ & 137 & 80.1 \\
\hline 11 years and above & 27 & 15.8 \\
\hline \multicolumn{3}{|l|}{ Unit Type } \\
\hline Emergency & 27 & 15.8 \\
\hline Operating Room & 11 & 6.4 \\
\hline Intensive Care Unit & 54 & 31.6 \\
\hline Gynecology/Delivery Room & 24 & 14.0 \\
\hline Operating Units & 30 & 17.5 \\
\hline Pediatrics & 14 & 8.2 \\
\hline $\begin{array}{l}\text { Administration and others (Polyclinic. } \\
\text { Infection Control. Education etc.) }\end{array}$ & 11 & 6.4 \\
\hline \multicolumn{3}{|l|}{ Experience in that unit } \\
\hline 1 year below & 28 & 16.4 \\
\hline $1-10$ & 136 & 79.5 \\
\hline \multirow[t]{2}{*}{11 years and above } & 7 & 4.1 \\
\hline & Mean \pm SD & Min-Max \\
\hline Age (years) & $26.27 \pm 7.46$ & $18-55$ \\
\hline
\end{tabular}

\section{Nurses' Administration Characteristics of IM Injection}

As shown in Table 2, 40.4\% of the nurses administer IM injections quite often (more than five times per week), and they predominantly prefer DG site (83.6\%) for delivery of medication through IM (except vaccines). The important factors that affect the selection of site for IM injection are the following: easiness to determine the site $(55 \%)$ and being suggested during nursing training $(55 \%)$.

It was found that $74.9 \%$ of the nurses had not recently received any training on IM injection sites whereas $73.7 \%$ did not read literature lately.

\section{Recognition of Possible Complications in Terms of IM Injection Sites by Nurses}

When nurses' knowledge about the probable complications at IM injection sites was inquired, it was revealed that some nurses did not consider some complications, such as pain/discomfort, sciatic nerve injury, bone and vein damage, infection, necrosis, tissue damage, nodule or stiffness, abscess, contracture, hematoma, to be risky (Table 3 ).

\section{The Effect of Individual and Professional Characteristics} of Nurses on the Selection of IM Injection Site

As shown in Table 4, nurses' ages, their professional education status, and their experience were found to have no impact on their selection of site to administer medication through IM injection ( $p>0.05$ ). In contrast, the type of unit played a role in determining injection site. Accordingly, the nurses working in the operating room and the pediatric clinic preferred the deltoid site; ICU and pediatrics nurses who working, preferred lateral femoral site; nurses who working in emergency preferred VG site, emergency, ICU, gynecology/delivery room, and operating units' nurses who working, preferred DG site.

The duration of experience in the unit they were working was found to be effective only on determining lateral femoral site for IM injection. This state of being statistically significant was determined to be related to the nurses working in the same unit for 1-10 years.

Table 2. Nurses' administration characteristics of IM injection $(n=171)$

\begin{tabular}{|c|c|c|c|c|}
\hline \multicolumn{3}{|c|}{ Characteristics of IM Injection Practice } & $\mathbf{n}$ & $\%$ \\
\hline $\begin{array}{l}\text { Frequency of IM } \\
\text { Injection }\end{array}$ & $\begin{array}{l}\text { Quite often (more than } 5 \text { per week } \\
\text { Often (1-4 times per week) } \\
\text { Occasionally (less than } 4 \text { per mont } \\
\text { Rarely or never (once a month or }\end{array}$ & $\begin{array}{l}\text { h) } \\
\text { ever) }\end{array}$ & $\begin{array}{l}69 \\
42 \\
35 \\
25 \\
\end{array}$ & $\begin{array}{l}40.4 \\
24.6 \\
20.5 \\
14.6\end{array}$ \\
\hline \multirow{4}{*}{$\begin{array}{l}\text { Preferred site for IM } \\
\text { route } \quad \text { (except } \\
\text { vaccines) }\end{array}$} & Deltoid muscle/ site & $\begin{array}{l}\text { Yes } \\
\text { No }\end{array}$ & $\begin{array}{c}6 \\
165\end{array}$ & $\begin{array}{c}3.5 \\
96.5\end{array}$ \\
\hline & $\begin{array}{l}\text { Vastus lateralis muscle/ Lateral } \\
\text { femoral site }\end{array}$ & $\begin{array}{l}\text { Yes } \\
\text { No }\end{array}$ & $\begin{array}{c}53 \\
118 \\
\end{array}$ & $\begin{array}{l}31.0 \\
69.0 \\
\end{array}$ \\
\hline & Ventrogluteal muscle/ site & $\begin{array}{l}\text { Yes } \\
\text { No }\end{array}$ & $\begin{array}{r}16 \\
155\end{array}$ & $\begin{array}{c}9.4 \\
90.6 \\
\end{array}$ \\
\hline & Dorsogluteal muscle/ site & $\begin{array}{l}\text { Yes } \\
\text { No }\end{array}$ & $\begin{array}{c}143 \\
28\end{array}$ & $\begin{array}{l}83.6 \\
16.4 \\
\end{array}$ \\
\hline \multirow{10}{*}{$\begin{array}{l}\text { Factors affecting site } \\
\text { selection for IM } \\
\text { injection* }\end{array}$} & \multicolumn{2}{|l|}{ Easy to identify site } & 94 & 55.0 \\
\hline & \multicolumn{2}{|l|}{ Site provides comfort for nurse } & 44 & 25.7 \\
\hline & \multicolumn{2}{|c|}{ Away from large blood vessels and nerves } & 92 & 53.8 \\
\hline & \multicolumn{2}{|l|}{ Usable in every age group } & 46 & 26.9 \\
\hline & \multicolumn{2}{|c|}{ A recommended site in new nursing literature } & 33 & 19.3 \\
\hline & \multicolumn{2}{|c|}{ Not being able to deliver to other sites safely } & 39 & 22.8 \\
\hline & \multicolumn{2}{|l|}{ Less likelihood of complications } & 72 & 42.1 \\
\hline & \multicolumn{2}{|l|}{ Being a traditional site } & 42 & 24.6 \\
\hline & \multicolumn{2}{|c|}{ Being suggested during nursing training } & 94 & 55.0 \\
\hline & \multicolumn{2}{|c|}{$\begin{array}{l}\text { Easy to administer large volume medication } \\
\text { with irritating nature }\end{array}$} & 64 & 37.4 \\
\hline $\begin{array}{l}\text { Training about IM } \\
\text { Injection Sites }\end{array}$ & \multicolumn{2}{|l|}{$\begin{array}{l}\text { Received } \\
\text { No }\end{array}$} & $\begin{array}{c}43 \\
128\end{array}$ & $\begin{array}{l}25.1 \\
74.9\end{array}$ \\
\hline $\begin{array}{l}\text { Literature about IM } \\
\text { Injection Sites }\end{array}$ & \multicolumn{2}{|l|}{ Read } & $\begin{array}{c}45 \\
126\end{array}$ & $\begin{array}{l}26.3 \\
73.7\end{array}$ \\
\hline
\end{tabular}

Table 3. Nurses' recognition of possible complications in terms of IM injection site $(\mathrm{n}=171)$

\begin{tabular}{|c|c|c|c|c|c|c|c|c|}
\hline \multirow[b]{2}{*}{ Complications } & \multicolumn{2}{|c|}{$\begin{array}{l}\text { Deltoid } \\
\text { site }\end{array}$} & \multicolumn{2}{|c|}{$\begin{array}{c}\text { Lateral } \\
\text { femoral site }\end{array}$} & \multicolumn{2}{|c|}{$\begin{array}{l}\text { Ventroglut } \\
\text { eal site }\end{array}$} & \multicolumn{2}{|c|}{$\begin{array}{l}\text { Dorsoglute } \\
\text { al site }\end{array}$} \\
\hline & n & $\%$ & $\mathbf{n}$ & $\%$ & $\mathbf{n}$ & $\%$ & $\mathbf{n}$ & $\%$ \\
\hline 1. Pain/discomfort & & & & & & & & \\
\hline Yes & 128 & 74.9 & 104 & 60.8 & 80 & 46.8 & 103 & 60.2 \\
\hline No & 43 & 25.1 & 67 & 39.2 & 91 & 53.2 & 68 & 39.8 \\
\hline \multicolumn{9}{|l|}{ 2. Sciatic Nerve } \\
\hline Injury & 17 & 9.9 & 39 & 22.8 & 47 & 27.5 & 115 & 67.3 \\
\hline $\begin{array}{l}\text { Yes } \\
\text { No }\end{array}$ & 154 & 90.1 & 132 & 77.2 & 124 & 72.5 & 56 & 32.7 \\
\hline \multicolumn{9}{|l|}{ 3. Injury to bone } \\
\hline Yes & 46 & 26.9 & 47 & 27.5 & 50 & 29.2 & 43 & 25.1 \\
\hline No & 125 & 73.1 & 124 & 72.5 & 121 & 70.8 & 128 & 74.9 \\
\hline \multicolumn{9}{|l|}{ 4. Injury to vein } \\
\hline Yes & 36 & 21.1 & 32 & 18.7 & 37 & 21.6 & 52 & 30.4 \\
\hline No & 135 & 78.9 & 139 & 81.3 & 134 & 78.4 & 119 & 69.6 \\
\hline \multicolumn{9}{|l|}{ 5. Infection } \\
\hline Yes & 64 & 37.4 & 60 & 35.1 & 55 & 32.2 & 69 & 40.4 \\
\hline No & 107 & 62.6 & 111 & 64.9 & 116 & 67.8 & 102 & 59.6 \\
\hline \multicolumn{9}{|l|}{ 6. Necrosis } \\
\hline Yes & 48 & 28.1 & 37 & 21.6 & 37 & 21.6 & 48 & 28.1 \\
\hline No & 123 & 71.9 & 134 & 78.4 & 134 & 78.4 & 123 & 71.9 \\
\hline \multicolumn{9}{|l|}{ 7. Tissue damage } \\
\hline Yes & 62 & 36.3 & 41 & 24.0 & 45 & 26.3 & 53 & 31.0 \\
\hline No & 109 & 63.7 & 130 & 76.0 & 126 & 73.7 & 118 & 69.0 \\
\hline \multicolumn{9}{|l|}{ 8. Nodule or stiffness } \\
\hline Yes & 57 & 33.3 & 57 & 33.3 & 47 & 27.5 & 78 & 45.6 \\
\hline No & 114 & 66.7 & 114 & 66.7 & 124 & 72.5 & 93 & 54.4 \\
\hline \multicolumn{9}{|l|}{ 9. Abscess } \\
\hline Yes & 66 & 38.6 & 47 & 27.5 & 43 & 25.1 & 82 & 48.0 \\
\hline No & 105 & 61.4 & 124 & 72.5 & 128 & 74.9 & 89 & 52.0 \\
\hline \multicolumn{9}{|l|}{ 10. Contracture } \\
\hline Yes & 12 & 7.0 & 17 & 9.9 & 20 & 11.7 & 17 & 9.9 \\
\hline No & 159 & 93.0 & 154 & 90.1 & 151 & 88.3 & 154 & 90.1 \\
\hline \multicolumn{9}{|l|}{ 11. Haematoma } \\
\hline Yes & 40 & 23.4 & 30 & 17.5 & 34 & 19.9 & 45 & 26.3 \\
\hline No & 131 & 76.6 & 141 & 82.5 & 137 & 80.1 & 126 & 73.7 \\
\hline
\end{tabular}




\section{Discussion}

An IM injection, one of the parenteral implementations, is an invasive technique that is frequently used for administering medications. ${ }^{1,18}$ Nurses who deliver IM injection are responsible for administering the right drug to the right patient at the correct dose at the right time via appropriate route and register all the details. ${ }^{1,2,4,5,7}$ The literature shows that VG site can be safely used for IM injection since it does not have large blood vessels or nerves and it is away from bone tissue. ${ }^{4,22}$ Even though VG site is described as the safest site for IM injection, majority of the nurses prefer DG site. ${ }^{2,17}$ The current study was conducted to investigate the sites chosen by nurses for IM injections and determine the factors that affect such choices.

\section{Nurses' Features of IM Injection Administration}

It was found that nurses administered IM injections quite often and preferred DG site to a greater extent while delivering drug through IM route (except for vaccines). According to the literature, VG site is easily identified because of easy positioning of the patient and feeling osteophyte by hand readily; however, nurses abstain from using this site because of the fear of hurting the patient and owing to the lack of sufficient knowledge and skills and thereby opt for DG site..$^{7,15}$ Greenway ${ }^{15}$ states that nurses did not know how to administer the injection to VG site; therefore, they were reluctant to use this site

Table 4. The effect on nurses' individual and professional characteristics on the selection of IM injection site $(\mathrm{n}=171)$

\begin{tabular}{|c|c|c|c|c|c|c|c|c|c|c|c|c|c|c|c|c|c|}
\hline \multirow{3}{*}{\multicolumn{2}{|c|}{ Individual and Professional Char. }} & \multicolumn{4}{|c|}{ Deltoid site } & \multicolumn{4}{|c|}{ Lateral femoral site } & \multicolumn{4}{|c|}{ Ventrogluteal site } & \multicolumn{4}{|c|}{ Dorsogluteal site } \\
\hline & & \multicolumn{2}{|c|}{ Yes } & \multicolumn{2}{|c|}{ No } & \multicolumn{2}{|c|}{ Yes } & \multicolumn{2}{|c|}{ No } & \multicolumn{2}{|c|}{ Yes } & \multicolumn{2}{|c|}{ No } & \multicolumn{2}{|c|}{ Yes } & \multicolumn{2}{|c|}{ No } \\
\hline & & $\mathbf{n}$ & $\%$ & $\mathbf{n}$ & $\%$ & $\mathbf{n}$ & $\%$ & $\mathbf{N}$ & $\%$ & n & $\%$ & $\mathbf{n}$ & $\%$ & $\mathbf{n}$ & $\%$ & $\mathbf{n}$ & $\%$ \\
\hline $\begin{array}{l}\text { Age Groups } \\
\text { (Year) }\end{array}$ & $\begin{array}{l}18-25 \\
26-33 \\
34-41 \\
42 \text { and } \uparrow\end{array}$ & $\begin{array}{l}5 \\
1 \\
0 \\
0\end{array}$ & $\begin{array}{c}83.3 \\
16.7 \\
0.0 \\
0.0 \\
=1.69 \\
\end{array}$ & $\begin{array}{c}97 \\
43 \\
18 \\
7 \\
=0.63 \\
\end{array}$ & $\begin{array}{c}58.8 \\
26.1 \\
10.9 \\
4.2\end{array}$ & $\begin{array}{c}29 \\
12 \\
9 \\
3\end{array}$ & $\begin{array}{c}54.7 \\
22.6 \\
17.0 \\
5.7 \\
\\
.099\end{array}$ & $\begin{array}{c}73 \\
32 \\
9 \\
4 \\
\\
0.25 \\
\end{array}$ & $\begin{array}{c}61.9 \\
27.1 \\
7.6 \\
3.4\end{array}$ & $\begin{array}{l}9 \\
3 \\
3 \\
1\end{array}$ & $\begin{array}{c}56.3 \\
18.8 \\
18.8 \\
6.3 \\
1.703 \\
\end{array}$ & $\begin{array}{c}93 \\
41 \\
15 \\
6 \\
\end{array}$ & $\begin{array}{c}60.0 \\
26.5 \\
9.7 \\
3.9 \\
6 \\
\end{array}$ & $\begin{array}{l}84 \\
38 \\
15 \\
6 \\
\chi^{2} \\
\end{array}$ & $\begin{array}{c}58.7 \\
26.6 \\
10.5 \\
4.2 \\
\\
0.385\end{array}$ & $\begin{array}{c}18 \\
6 \\
3 \\
1 \\
=0.9 \\
\end{array}$ & $\begin{array}{r}64.3 \\
21.4 \\
10.7 \\
3.6 \\
\\
\end{array}$ \\
\hline $\begin{array}{l}\text { Professional } \\
\text { Education }\end{array}$ & $\begin{array}{l}\text { Vocational High } \\
\text { School } \\
\text { Associate's Degree } \\
\text { Bachelor }\end{array}$ & $\begin{array}{l}3 \\
2\end{array}$ & $\begin{array}{l}50.0 \\
33.3 \\
16.7 \\
=1.07\end{array}$ & $\begin{array}{r}104 \\
28 \\
33 \\
=0.58 \\
\end{array}$ & $\begin{array}{l}63.0 \\
17.0 \\
20.0\end{array}$ & $\begin{array}{c}34 \\
10 \\
9 \\
\quad \\
\end{array}$ & $\begin{array}{l}64.2 \\
18.9 \\
17.0 \\
.433\end{array}$ & $\begin{array}{l}73 \\
20 \\
25 \\
0.80\end{array}$ & $\begin{array}{l}61.9 \\
16.9 \\
21.2\end{array}$ & $\begin{array}{l}15 \\
2 \\
1\end{array}$ & $\begin{array}{l}81.3 \\
12.5 \\
6.3 \\
\\
2.890\end{array}$ & $\begin{array}{r}94 \\
28 \\
33 \\
=0.2\end{array}$ & $\begin{array}{l}60.6 \\
18.1 \\
21.3\end{array}$ & $\begin{array}{l}89 \\
23 \\
31 \\
\\
\chi^{2}\end{array}$ & $\begin{array}{r}6.22 \\
16.1 \\
21.7 \\
\\
2.492\end{array}$ & $\begin{array}{c}18 \\
7 \\
3 \\
\\
=0.2\end{array}$ & $\begin{array}{l}64.3 \\
25.0 \\
10.7 \\
8 \\
\end{array}$ \\
\hline $\begin{array}{l}\text { Experience } \\
\text { in Job }\end{array}$ & $\begin{array}{l}1 \text { year below } \\
1-10 \\
11 \text { years and above }\end{array}$ & $\begin{array}{l}1 \\
5\end{array}$ & $\begin{array}{c}16.7 \\
83.3 \\
0.0 \\
=3.39 \\
\end{array}$ & $\begin{array}{c}6 \\
132 \\
27 \\
=0.18 \\
\end{array}$ & $\begin{array}{c}3.8 \\
80.0 \\
16.4\end{array}$ & $\begin{array}{c}4 \\
39 \\
10 \\
\quad \gamma \\
\end{array}$ & $\begin{array}{c}7.5 \\
73.6 \\
18.9 \\
108\end{array}$ & $\begin{array}{c}3 \\
98 \\
17 \\
0.21 \\
\end{array}$ & $\begin{array}{c}2.5 \\
83.1 \\
14.4 \\
\end{array}$ & $\begin{array}{c}0 \\
13 \\
3 \\
\quad \times \\
\end{array}$ & $\begin{array}{c}0.0 \\
81.3 \\
18.8 \\
0.823 \\
\end{array}$ & $\begin{array}{c}7 \\
124 \\
24 \\
=0.6 \\
\end{array}$ & $\begin{array}{c}4.5 \\
80.0 \\
15.5 \\
3 \\
\end{array}$ & $\begin{array}{c}5 \\
115 \\
23 \\
\chi^{2} \\
\end{array}$ & $\begin{array}{c}3.5 \\
80.4 \\
16.1 \\
0.818 \\
\end{array}$ & $\begin{array}{c}2 \\
22 \\
4 \\
=0.6\end{array}$ & $\begin{array}{c}7.1 \\
78.6 \\
14.3 \\
4 \\
\end{array}$ \\
\hline Unit Type & $\begin{array}{l}\text { Emergency } \\
\text { Operating Room } \\
\text { Intensive Care Unit } \\
\text { Gynecology/Delivery } \\
\text { Operating Units } \\
\text { Pediatrics } \\
\text { Admin. \& others * }\end{array}$ & $\begin{array}{l}3 \\
0 \\
0 \\
0 \\
2\end{array}$ & $\begin{array}{c}16.7 \\
50.0 \\
0.0 \\
0.0 \\
0.0 \\
33.3 \\
0.0 \\
=\mathbf{2 7 . 4 8} \\
\end{array}$ & $\begin{array}{c}26 \\
8 \\
54 \\
24 \\
30 \\
12 \\
11 \\
\\
0<0.0 \\
\end{array}$ & $\begin{array}{c}15.8 \\
4.8 \\
32.7 \\
14.5 \\
18.2 \\
7.3 \\
6.7\end{array}$ & $\begin{array}{c}10 \\
2 \\
18 \\
2 \\
2 \\
11 \\
8 \\
\chi\end{array}$ & $\begin{array}{c}18.9 \\
3.8 \\
34.0 \\
3.8 \\
3.8 \\
20.8 \\
15.1 \\
\mathbf{9 . 2 8 2} ; \\
\end{array}$ & $\begin{array}{c}17 \\
9 \\
36 \\
22 \\
28 \\
3 \\
3 \\
<0.0 \\
\end{array}$ & $\begin{array}{c}14.4 \\
7.6 \\
30.5 \\
18.6 \\
23.7 \\
2.5 \\
2.5 \\
1 \\
\end{array}$ & $\begin{array}{l}8 \\
2 \\
1 \\
1 \\
2 \\
0 \\
2 \\
\chi\end{array}$ & $\begin{array}{c}50.0 \\
12.5 \\
6.3 \\
6.3 \\
12.5 \\
0.0 \\
12.5 \\
\mathbf{2 1 . 1 5 4} \\
\end{array}$ & $\begin{array}{c}19 \\
9 \\
53 \\
23 \\
28 \\
14 \\
9 \\
p=0.0\end{array}$ & $\begin{array}{c}12.3 \\
5.8 \\
34.2 \\
14.8 \\
18.1 \\
9.0 \\
5.8 \\
\mathbf{0 2} \\
\end{array}$ & $\begin{array}{c}27 \\
7 \\
42 \\
22 \\
28 \\
6 \\
11 \\
\chi^{2}=3\end{array}$ & $\begin{array}{c}18.9 \\
4.9 \\
29.4 \\
15.4 \\
19.6 \\
4.2 \\
7.7 \\
\mathbf{1 9 0 ;} p\end{array}$ & $\begin{array}{c}0 \\
4 \\
12 \\
2 \\
2 \\
8 \\
0 \\
\\
\end{array}$ & $\begin{array}{c}0.0 \\
14.3 \\
42.9 \\
7.1 \\
7.1 \\
28.6 \\
0.0 \\
\mathbf{1} \\
\end{array}$ \\
\hline $\begin{array}{l}\text { Experience } \\
\text { in that Unit }\end{array}$ & $\begin{array}{l}1 \text { year below } \\
1-10 \\
11 \text { years and above }\end{array}$ & $\begin{array}{l}3 \\
3 \\
0\end{array}$ & $\begin{array}{c}50.0 \\
50.0 \\
0.0 \\
=5.23 \\
\end{array}$ & $\begin{array}{c}25 \\
133 \\
7 \\
=0.07\end{array}$ & $\begin{array}{c}15.2 \\
80.6 \\
4.2\end{array}$ & $\begin{array}{c}5 \\
43 \\
5 \\
\quad \\
\end{array}$ & $\begin{array}{c}9.4 \\
81.1 \\
9.4 \\
.635 ; \\
\end{array}$ & $\begin{array}{c}23 \\
93 \\
2 \\
\mathbf{0 . 0 2}\end{array}$ & $\begin{array}{c}19.5 \\
78.8 \\
1.7 \\
\end{array}$ & $\begin{array}{c}1 \\
14 \\
1 \\
\quad \\
\end{array}$ & $\begin{array}{c}6.3 \\
87.5 \\
6.3 \\
1.446 \\
\end{array}$ & $\begin{array}{c}27 \\
122 \\
6 \\
=0.4\end{array}$ & $\begin{array}{c}17.4 \\
78.7 \\
3.9 \\
5 \\
\end{array}$ & $\begin{array}{c}24 \\
115 \\
4 \\
\chi^{2}\end{array}$ & $\begin{array}{c}16.8 \\
80.4 \\
2.8 \\
\\
3.761\end{array}$ & $\begin{array}{c}4 \\
21 \\
3 \\
=0.1\end{array}$ & $\begin{array}{l}14.3 \\
75.0 \\
10.7 \\
3 \\
\end{array}$ \\
\hline
\end{tabular}

* Polyclinic. Infection Control. Education etc.

According to the study conducted by Walsh and Brophy, nurses reported preferentially using the DG site and more nurses $(85 \%)$ based their site selection upon their level of comfort. ${ }^{23}$ Sar1 et al. studied the practices that nurses apply in IM injection and found out that more than half of the nurses reported the use of DG site for injection. ${ }^{8}$ The results of this study, similar to those in the literature, emphasize that DG site is actively used for IM injection, although it is not recommended. Also, they imply that nurses face difficulties in reflecting evidence-based practices into their professional life. The most significant reason why nurses prefer DG site for IM injection was found to be the ease of identifying the injection site. In the past, DG site was a commonly used site for IM injection and it could be determined in three different ways. Nurses identify the injection area at DG site by using patient's anatomic spots as a base, and thereby they do not feel anxiety over whether it is the right spot or not. In contrast, because VG site is determined by placing the palm of the hand over the head of femur, the size of the hand plays a role in determining the right spot, which causes nurses to feel anxious. On the other hand, it is not possible for nurses to identify the site in children by using their own hands. ${ }^{5,24}$ The study by Wynaden et al. revealed that determining VG site, small area for injection which may necessitate the use of other sites for patients requiring repeated injections and determing anatomically it for this reason, nurses prefer DG site. ${ }^{24}$ Strohfus et al. state that it is more challenging for nurses with inexperience and newstarters to spot and use VG site. ${ }^{25}$ To sum up, the present study and other studies emphasize that nurses feel confident about themselves in identifying DG site and thereby, they favor this site. However, alternative methods have been developed to determine VG site and reliability of these methods have been 
tested. ${ }^{2,26}$ The course of action to take at this point is to disseminate the results of these studies.

Another important reason for the preference of DG site is that the very same site is taught in nursing curriculum. The use of DG site has not been recommended in Essentials of nursing course books recently due to sciatic nerve damages. As a safer alternative to DG site, VG site is suggested. ${ }^{2,8}$

We live in the age of information and the amount of required knowledge, skills, attitudes, and behavior is increasing, which requires students to keep track of such changes after graduation and update their knowledge and skills. In teaching and learning theories, permanent behavior change is said to be the main objective. However, implementing the changing practices into professional nursing in the aftermath of the graduation and ensuring permanent behavior change are the most challenging part of lifelong learning process. ${ }^{2,8,24}$ The findings of this study show that reorganizing an acquired behavior in light of the newly learned information is difficult. The responsibility also falls to the nursing schools in this matter. It becomes increasingly important that faculty members collaborate closely with managers of practice administration to promote nurses' lifelong learning process.

This study revealed that most of the nurses have not been given any training regarding IM injection sites recently and they do not follow current affairs. Though VG is the safest site for IM injection, DG site is preferred in practice, which shows that nurses have not learned the advantages of VG site sufficiently enough and they do not keep themselves updated with current information. Besides, literature shows that nurses have not received any kind of training other than basic training of IM injection method, although IM medication administration causes iatrogenic complications. ${ }^{6,27}$ Study by Hensel and Springmyer revealed that nurses are not informed about current recommendations issued by professional nursing institutions and they continue their profession with practices taught during their basic training. ${ }^{28}$ The nurses witness traditional ritualized injection administration applied by other nurses in many practices and thereby, they do not revise current research about the issue most of the time. In conclusion, the present study and the studies reviewed demonstrate that nurses' knowledge of IM injection administration and selection of the right site for administration is based on old resources and they are not aware of the developments.

\section{Nurses' Recognition of Possible Complications in Terms of IM Injection Site}

Knowledge of the nurses about the possible complications that might occur at an IM injection site was investigated. Accordingly, the following observations were made: they knew that some pain/discomfort do not occur although such problems might develop in all the administration sites; although there is a risk of injury to nerves in the deltoid site, most of them claimed that nerve damage does not occur; even though there is no risk of a possible sciatic nerve damage at VG site, some nurses claimed such damage would develop; although bone injury, vein injury, infection, necrosis, tissue damage, nodule or stiffness, abscess, contracture due to immobility, and hematoma are possible risks at all sites, some nurses did not report such complications as risks. These findings imply that nurses do not have necessary knowledge of what possible complications might occur at IM injection sites. IM injection-based complications are abscess, necrosis, hematoma, ecchymosis, infection, pain, periostitis, and injury to vein and nerve. ${ }^{2,4,7}$ However, the most notable complication is sciatic nerve injury and it particularly takes place during injections to the DG site..$^{2,11,23}$ It has also been stated that the anatomical location of the sciatic nerve can vary from one individual to another, and the imaginary line used to determine the site can often be wrong, and injections to the DG site always carry a risk of injury, particularly to the nerves. ${ }^{4,7}$ Relevant studies reveal that complications often arise due to IM injection to the DG site and most of these complications are caused by lack of knowledge and the use of inappropriate techniques. ${ }^{7,19,29}$ The findings of the current study clearly show that nurses need to know the anatomical structure of the administration site and make appropriate choice of the site to avoid possible complications.

\section{The Effect on Individual and Professional Characteristics of Nurses on the Selection of IM Injection Site}

It was seen that nurses' age, education status, and their experience have no impact on the selection of IM injection site. It is important to choose a site away from large blood vessels, nerve and bone structures. ${ }^{25}$ Although VG site is advocated as the first preference in clinical environment, the DG site, vastus lateralis, and deltoid muscle are used despite their well-known potential risks. ${ }^{4,7}$ It is a known fact that nurses face a variety of problems in selecting the VG site and administration despite the updated nursing curriculum. In addition, the inability to implement evidence-based studies into practice, nurses' resistance against changing practices in developing technologies, and their failure to adopt these practices constitute the most compelling problems. ${ }^{2}$ Nursing profession is also teamwork. Because a different site choice is likely to cause various problems among the team members, the new graduate nurses maintain certain practices without questioning and disturbing the routine in that clinic. The current study reveals the fact that nurses predominantly prefer the DG site for IM injection site, which is confirmed by referring to the literature.

It has been reported that the type of unit in which the nurses work plays a role in determining the injection site. Those working in operating room and pediatrics choose deltoid site. The injection site needs to be decided after the evaluation of patient's age, the volume of medication, and present muscle development. 5 American Academy of Pediatrics (APA) recommends the use of deltoid muscle in children aged three and above and advocates the vastus lateralis as an alternative site. The findings of the study are consistent with literature and they show parallelism with the current practice of nurses in pediatrics who often prefer deltoid site for administering vaccinations. It was observed that deltoid site, which is easily identified, but not developed in quite many individuals, is preferred by nurses because operating room is a sterilized environment and it is more convenient to maintain the position of the patient. This site is used only for small volume medications and also in cases where it is not possible to deliver injection to other sites due to practices such as wound dressing. ${ }^{1}$

Lateral femoral site is often used by nurses in ICU and pediatrics. It is preferred in ICU because nurses do not disrupt patients' comfort during IM injection and they can easily reach administration site. To identify the injection site, the patient is asked to lie down face up or have a sitting position. ${ }^{21}$ On the other hand, nurses in pediatrics prefer lateral femoral site because of the fear of a potential sciatic nerve injury to DG site. ${ }^{14,17}$ The current study is compatible with literature in this respect and it explains why nurses choose this site in ICU and pediatrics.

VG site was found to be preferred by nurses working in emergency. It is preferred over other sites because it is easier to place the patient in that position and bone spurs are easily 
recognized by hand. ${ }^{2,15}$ Such findings explain the practice that nurses working in emergency units, where time matters greatly, opt for the $\mathrm{VG}$ site because of the easiness in determining the site in every position. However, the use of VG site would be expected to be preferred by nurses in ICU for similar reasons. In addition, the reason behind the use of this information by nurses in emergency more than the nurses in other units is a matter that needs to be qualitatively investigated. Thus, strategies should be developed for the nurses working in all other clinics to prefer the ventrogluteal site by taking advantage of the data obtained from ICU and emergency units In addition, it is suggested that IM injection to VG site should be taught by implementation to all nurses during the in-service training process.

DG site is preferred by nurses in emergency, ICU, gynecology/delivery room, and operating units. Despite not being recommended in the literature, ${ }^{4,9,22}$ DG site is employed in many units of the hospital because the nurses are not following the current literature. As emphasized strongly at many other occasions, the need to organize trainings about why VG site should be given priority under favorable conditions is demonstrated in this study. For this, in cooperation with the Ministry of Health; trainings about implementation to VG site should be organized to nurses working in all health institutions and the results should be monitored.

Nurses with 1-10 years of experience in the same unit were found to prefer lateral femoral site for IM injection. Lateral femoral site is a spot particularly preferred in babies, children until the age of three, and adults in units such as gynecology/delivery room, emergency, and ICU because of its easier accessibility and fewer associated risks compared with that of the DG site. ${ }^{1,21}$ The findings of this study indicate that experienced nurses do not prefer the DG site because of the risks it carries, and they do not use the VG site, as they may not have adequate knowledge and experience. For these reasons, they primarily choose lateral femoral site.

\section{Study Limitation}

The results of the study are based on the self-statements of nurses working at two hospitals. Additionally, the results of this study are limited to one city of Turkey. Thus, it is not possible to generalize the findings of the study to all nurses in Turkey.

In conclusion, nurses often opt for DG site while administering IM injection. Their knowledge regarding the actions to be taken in case of complications is insufficient and the selection of the site depends on many factors. In light of the study results, the following points should be noted:

- Students should be taught how to select site for IM injection in the light of up-to-date information and practices during basic nursing training

- Nurses' knowledge of IM drug administration and their practices should be updated through in-service-training

- Evidence-based IM injection practices should be followed and attendance in symposiums and conferences be encouraged

\section{Acknowledgments}

The authors would like to thank the Istanbul University Scientific Research Projects (IUBAP) Unit, which contributed to the study (Project No: BEK- 2016-21708).

\section{Conflict of Interest}

All authors declare no conflict of interest.

\section{Compliance of Ethical Statement}

Written consent was obtained from both hospitals through an information form describing the aim and scope of the study. Ethical committee approval was acquired ethical committee before conducting the study (09/08/2015-10840098604.01.01-E.163). Participant nurses were informed about the aim and benefits of the study along with their roles. Keeping the principle of voluntariness, their oral and written consents to participate in the study were ensured.

\section{Financial Disclosure/Funding}

This study was funded by the Scientific Research Project Unit at Istanbul University. We are grateful for their contributions (Project No: BEK- 2016-21708).

\section{Author Contribution}

NT, NK, and GÖA: designed the study; NT and GÖA: collected the data; NT and NK: analyzed the data; NT, NK, and GÖA: prepared the manuscript.

\section{References}

1. Kaya N, Palloş A. Parenteral drug management. In: Atabek Aştı T, Karadağ A, editors. Nursing Science and Art, Istanbul, TR: Akademi Basın ve Yayınc1lı; 2012:761-809.

2. Kaya N, Salmaslığlu A, Terzi B, Turan N, Acunaş B. The reliability of site determination methods in ventrogluteal area injection: A cross-sectional study. Int $J$ Nurs Stud. 2015;52(1):355-360. doi:10.1016/j.ijnurstu.2014.07.002.

3. Kaya N, Turan N, Özdemir Aydın G. Intramuscular injection to ventrogluteal site: A systematic review. Int $J$ Caring Sci. 2016;9(3):1168-1176. doi:10.7748/ns2004.03.18.25.39.c3560.

4. Potter PA, Perry AG, Stockert P, Hall A. Fundamentals of Nursing. 9th ed. Philadelphia, PA: Elsevier Health Sciences; 2016; p. 647-652.

5. Yıldız D, Kızıler E, Fidancı BE, Suluhan D. Çocuklara intramusküler enjeksiyon uygulamasında doğrular nelerdir? $J$ Nurs Sci. 2017;9(2):144-152. doi:10.5336/nurses.2016-51005.

6. Kim HJ, Park SH. Sciatic nerve injection injury. J Int Med Res. 2014;42(4):887-897. doi:10.1177/0300060514531924.

7. Boyd AE, DeFord LL, Mares JE, et al. Improving the Success Rate of Gluteal Intramuscular Injections. Pancreas. 2013;42:878-882. doi:10.1097/MPA.0b013e318279d552.

8. Sarı D, Şahin M, Yaşar E, Taşkıran N, Telli S. Investigation of Turkish nurses frequency and knowledge of administration of intramuscular injections to the ventrogluteal site: Results from questionnaires. Nurse Educ Today. 2017;56(9):47-51. doi:10.1016/j.nedt.2017.06.005.

9. Coskun H, Kilic C, Senture C. The evaluation of dorsogluteal and ventrogluteal injection sites: a cadaver study. J Clin Nurs.2016;25:1112-1119. doi:10.1111/jocn.13171.

10. Larkin TA, Ashcroft E, Elgellaieb A, Hickey BA. Ventrogluteal versus dorsogluteal site selection: A cross-sectional study of muscle and subcutaneous fat thicknesses and an algorithm incorporating demographic and anthropometric data to predict injection outcome. Int $J$ Nurs Stud. 2017;71:1-7. doi:10.1016/j.ijnurstu.2017.02.017.

11. Bağış S, Adam M, Leblebici ÜB, Karataş M, Güven AZ, Çeliker AR. Sciatic nerve injury due to intramuscular injection: electrophysiological findings and one-year follow-up. Turk $J$ Med Sci. 2012;42(5):913-917.

12. Craven RF, Hirnle CJ. Fundamentals of Nursing: Human Health and Function. 8th ed. Philadelphia, PA: Lippincott Williams\&Wilkins; 2016, p. 529-530.

13. Taylor C, Lillis C, LeMone P, Lynn P. Fundamentals of Nursing the Art and Science of Nursing Care. 7th ed. China: Wolters Kluwer, Lippincott Williams\&Wilkins; 2011, p. 797- 2842.

14. Min HJ, Kim YJ. Analysis of gluteal subcutaneous and muscle thickness in infants and children for application to intramuscular injection, autologous fat grafting, and gluteal artery perforator flaps. Arch Plast Surg. 2018;45(6):550-556. doi:10.5999/aps.2017.01760. 
15. Greenway K. Rituals in nursing: intramuscular injections. J Clin Nurs. 2014;23:3583-3588. doi:10.1111/jocn.12627.

16. Masuda S, Yasuhara Y, Tanioka T, et al. Comparison of gluteal muscle intramuscular injection sites of Japanese healthy subjects: considerations for optimal insertion of injection needle length. Open Journal of Psychiatry. 2016;6(2):203-212. doi:10.4236/ojpsych.2016.62025.

17. Cocoman A, Murray J. Recognizing the evidence and changing practice on injection site. Br J Nurs. 2010;19(18):11701174.doi:10.12968/bjon.2010.19.18.79050.

18. Berman A, Snyder S, Frandsen G. Kozier\&Erb's Fundamentals of Nursing: Concepts, Process, and Practice. 10th ed. New Jersey, NJ: Pearson; 2015; p. 797-803.

19. Smith SF, Duell D, Martin BC, et al. Clinical Nursing Skills: Basic to Advanced Skills. 9th ed. Upper Saddle River, NJ: Pearson Prentice Hall; 2016.

20. Kaya N, Turan N, Palloş AÖ. Dorsogluteal bölge intramusküler enjeksiyon uygulamak amaciyla kullanılmamalı mı? İ.̈̈.F.N. Hem Derg. 2012;20(2):146-153.

21. Ogston-Tuck S. Intramuscular injection technique: an evidencebased approach. Nursing Standard. 2014;29(4):52-63. doi:10.7748/ns.29.4.52.e9183.

22. Doğu Ö. The invisible tip of the iceberg; How often is the ventrogluteal area used? Journal of Education and Research in Nursing. 2016;13(1):7-10. doi:10.5222/HEAD.2016.239

23. Walsh L, Brophy K. Staff nurses' sites of choice for administering intramuscular injections toadult patients in the acute care setting. $J$ Adv Nurs. 2010;67(5):1034-1040 doi:10.1111/j.13652648.2010.05527.x.

24. Wynaden D, Tohotoa J, Omari OA, et al. Administering intramuscular injections: How does research translate into practice over time in the mental health setting? Nurse Educ Today. 2015;35:620-624. doi:10.1016/j.nedt.2014.12.008.

25. Strohfus PK, Paugh O, Tindell C, Molina-Shaver P. Evidence calls for practice change in intramuscular injection techniques. $J$ Nurs Educ Pract. 2018;8(2):83-92. doi:10.5430/jnep. v8n2p83.

26. Larkin TA, Elgellaie A, Ashcroft E. Comparison of the G and V methods for ventrogluteal site identification: Muscle and subcutaneous fat thicknesses and considerations for successful intramuscular injection. Int J Ment Health Nurs. 2018;27:631641. doi:10.1111/inm.12346.

27. Cook IF. Best vaccination practice and medically attended injection site events following deltoid intramuscular injection. Hum Vaccines Immunother. 2015;11(5):1184-1191. doi:10.1080 /21645515.2015.1017694.

28. Hensel D, Springmyer J. Do perinatal nurses still check for blood return when administering the hepatitis B vaccine? J Obstet Gynecol Neonatal Nurs. 2011;40(5):589-594. doi:10.1111/j.1552-6909.2011.01277.x.

29. Mclaws ML, Palenik CJ, Askarian M. Assessment of injection practice in primary health care facilities of Shiraz, Iran. $\quad A m$ $J$ Infect Control. 2014;42:300-304. doi:10.1016 /j.ajic.2013.09.006. 